\title{
Problems Associated with Qualifying Selected Industrial Structures in Terms of Charging Property Tax**
}

\section{Introduction}

Qualifying fixed assets of the entities conducting business activity for tax purposes requires that the evaluator has sufficient knowledge in the field of law, construction and engineering of the company. Difficulties which are encountered during the evaluation process result from imprecise and inconsistent provisions contained in the legislation which constitutes the basis for the qualification. They might result in lengthy and costly disputes between taxpayers and administrative authorities.

This issue is particularly complicated in the case of numerous objects located at large industrial plants, which are diversified in terms of their structure or function. Qualifying assets of the industrial plant to the category "structures", within the meaning of the Construction Law [5], results in them being subject to property tax.

The general rule is that buildings, or parts thereof, are subject to property tax only if they are associated with running a business activity. This is pursuant to article 2 section 1 clause 3 of the Law on Local Taxes and Fees [4]; in other cases, the tax liability does not arise. The tax base is the value of the structure, determined as of January 1 of the tax year, which is the basis for calculating the depreciation in this year, with no deduction of depreciation charges [4].

The article discusses the criteria for warehouses, storage tanks, reservoirs, foundations, supporting structures, technical equipment and process equipment, used for running a business activity, in terms of charging property tax. Examples of qualifying such structures located in the areas of large industrial plants were provided as well.

\footnotetext{
* AGH University of Science and Technology, Faculty of Mining Surveying and Environmental Engineering, Krakow, Poland

** The article was prepared within the scope of the AGH statutory research no. 11.11.150.005
} 


\section{Qualification Basis}

In accordance with the provisions of the Law on Local Taxes and Fees [4], the basis for the qualification of assets for charging property tax is the Construction Law [5]. This Act regulates the activities involving the design, construction, maintenance and demolition of civil structures, as well as defines the principles of the activities performed by the state administrative authorities in these areas.

In order to carry out a proper qualification of structures, it is essential to unambiguously define earlier the meanings of basic concepts used in these laws. Definitions of the following concepts: civil structure, building, structure, landscaping structure, as well as linear structure and building's infrastructure, have been presented in detail in art. 3 of the Construction Law [5, also cf. 1]. While analyzing the problems of qualifying the objects discussed in the paper, it is advisable to cite selected parts of the term "structure", as defined in article 3 of the above-mentioned Law.

And so, the "structure" means any civil structure which is not a building or an object of landscape architecture, such as: linear structures, viaducts, overpasses, tunnels, culverts, technical networks, storage tanks, freestanding industrial equipment or technical equipment, sewage treatment plants, landfill sites, waste water treatment plants, public utilities, and also construction parts of technical equipment, as well as foundations for machinery and equipment. The "linear structures" include water supply pipeline, channel, gas pipeline, heat pipeline, pipeline, electricity power line and overhead power transmission line, overhead cable line and underground line (placed directly in the ground), as well as cable ducts, where the cables installed in it do not constitute a civil structure nor part thereof, nor building's infrastructure.

The Law on Local Taxes and Fees [4] defines the concept of a "structure" in a slightly different manner. Pursuant to article 1a of this Act: the "structure" is an object, within the meaning of the Construction Law, which is not a building or an object of landscape architecture, as well as building's infrastructure under the provisions of the Construction Law associated with a civil structure, which provides for a possibility to use the object as intended.

The discrepancies in the definitions of the term "structure" contained in the Construction Law [5] and in the Law on Local Taxes and Fees [4] can become a significant impediment to the explicit qualification of objects for tax purposes.

Based on the interpretation of the legislation [3-5] and the experience of the authors [2], the general criteria for qualifying business assets of the entities conducting business activity for tax purposes were defined. As a result, these objects were divided into four basic categories [1]: a building, a structure, building's infrastructure and process equipment or technical equipment.

In the above list, only buildings and structures are civil structures within the meaning of the Construction Law [5]. On the other hand, according to the Law on Local Taxes and Fees [4], property tax on real estate of the entities conducting business activities shall be charged for the buildings, structures and building's infrastructure. 
Due to the inconsistent definitions contained in [4,5], according to the authors, the listed assets should be further divided into sub-groups, taking into account their location, method of connection with other objects, as well as their engineering function in the plant.

Chapters 3 and 4 analyze the criteria for qualifying two selected industrial civil structures:

- warehouses, storage tanks and reservoirs,

- foundations and supporting structures.

The specified categories have been illustrated with examples of the objects located at large industrial plants [2].

\section{Warehouses, Storage Tanks and Reservoirs}

Warehouses, storage, tanks and reservoirs can potentially be qualified to the above categories of assets specified in the Construction Law [5]. Therefore, buildings can be distinguished here, with installations and technical equipment, thus in accordance with art. 3 of the Law - civil structures that are permanently affixed to land, separated from the space by building envelopes, and having foundations and a roof, such as warehouses, for example (Fig. 1).

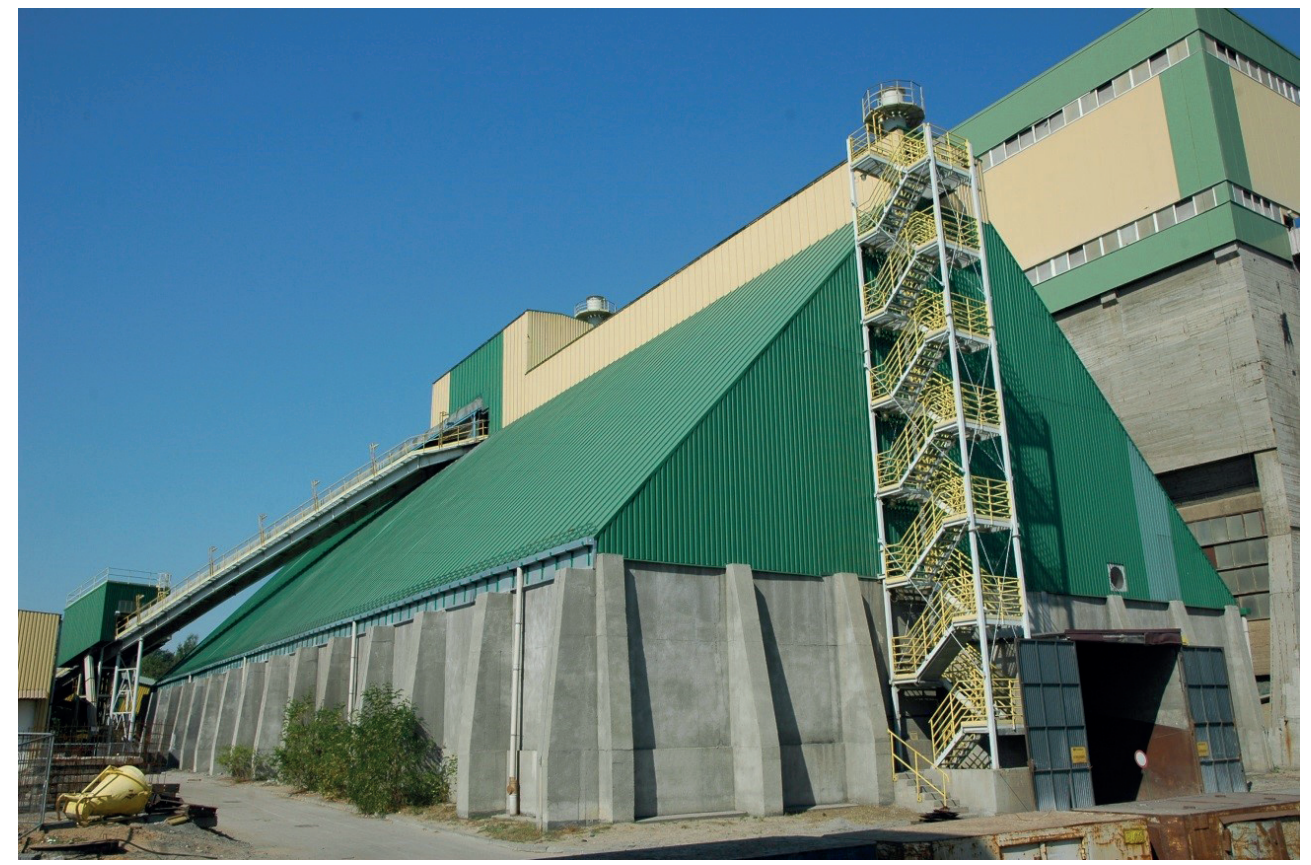

Fig. 1. Copper ore warehouse at the industrial plant - a building

Source: [2] 
Warehouses, storage tanks and reservoirs can be qualified as structures, together with installations and equipment, with which they form the technical and utility whole, if they are independent objects, permanently affixed to land, e.g.:

- warehouse shed of a hangar structure, however, pursuant to art. 3 of the Law [5], does not meet the requirements of the definition of a building because it lacks separation from the space by building envelopes (Fig. 2);

- storage tank or reservoir, expressly mentioned in the definition of a structure; it is an object located outside the building, with housing or without (Figs 3-5).

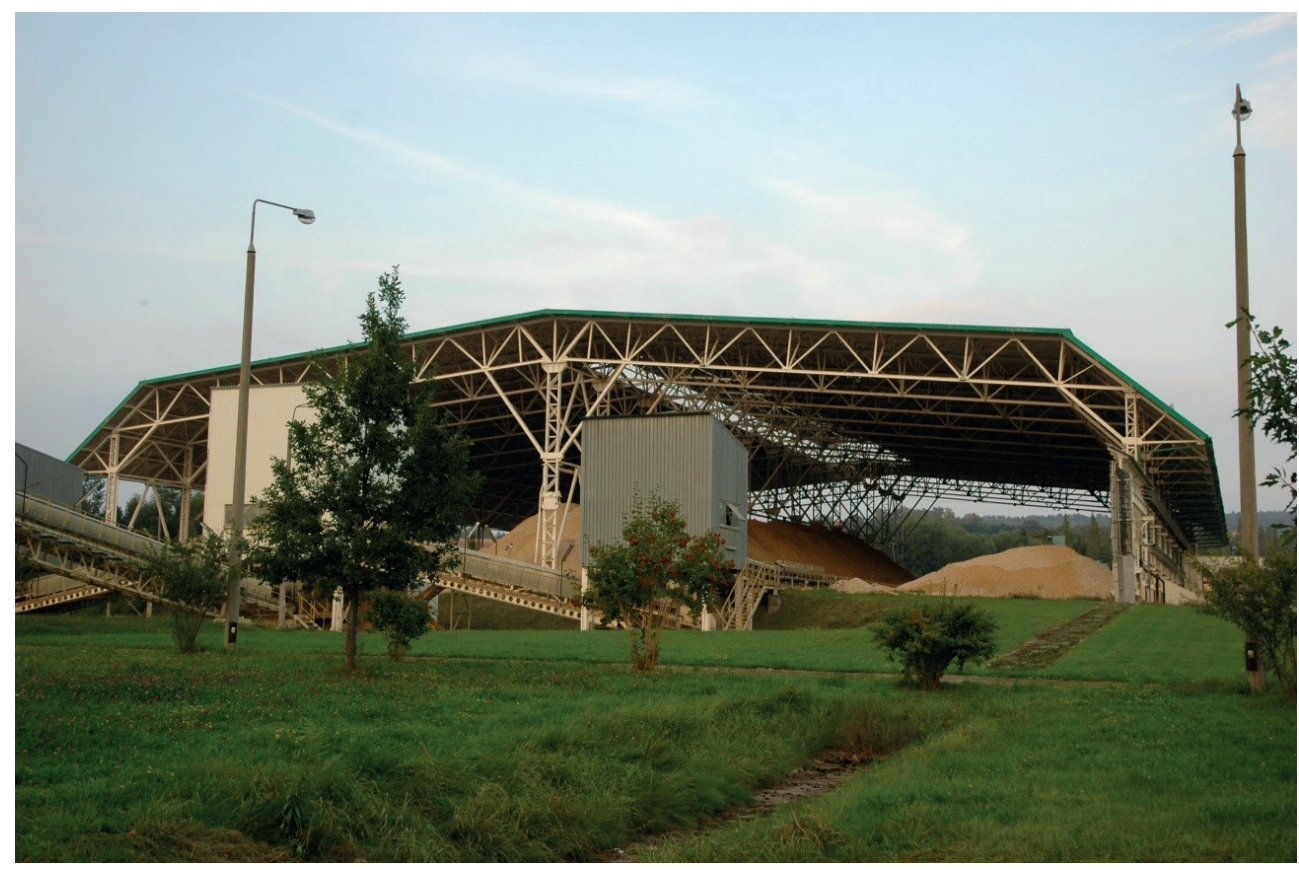

Fig. 2. Limestone storage site at the industrial plant - a structure Source: [2]

Storage tanks can also be assigned to the category of building's infrastructure, if they are elements of technical equipment associated with a particular civil structure and they ensure the possibility to use this object as intended, such as facilities for the treatment or accumulation of sewage, e.g.: a sewage holding tank at an industrial plant.

On the other hand, storage tanks can be part of process equipment or technical equipment, i.e. assets necessary to ensure the proper implementation of the engineering process executed in a given plant. 


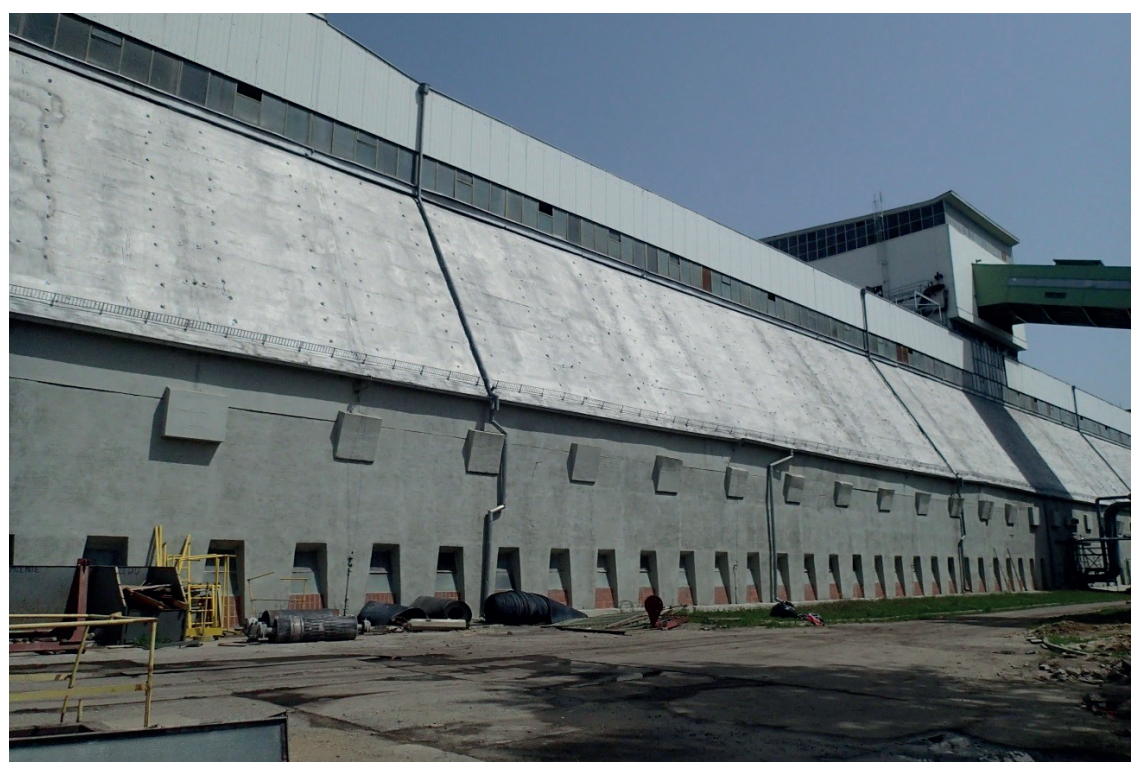

Fig. 3. Carbon reservoir at the industrial plant - a structure

Source: [2]

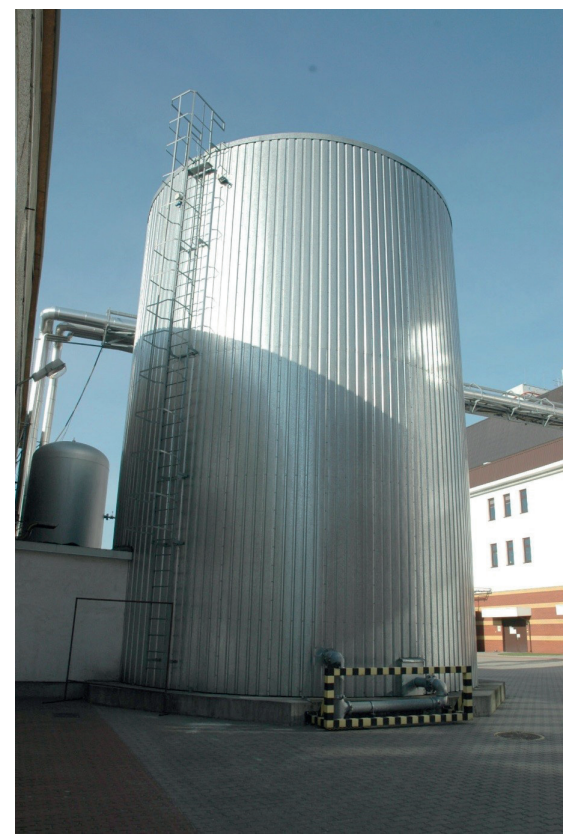

Fig. 4. Fire water storage tank at the industrial plant - the storage tank and the foundation on which it rests are structures

Source: [2] 


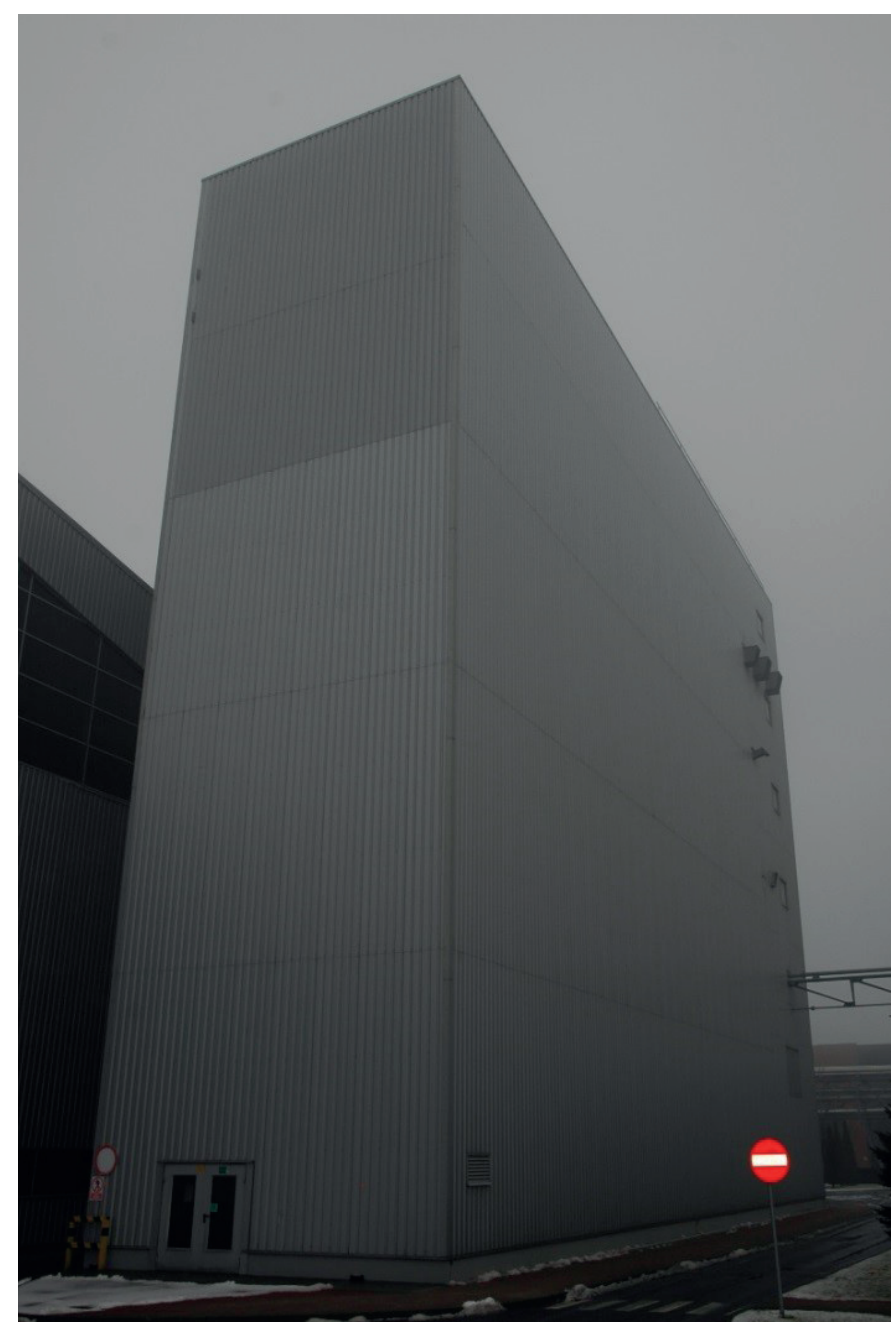

Fig. 5. A complex of malt silos at the industrial plant - a structure Source: [2]

They may be attached to special foundations or supporting structures located both outside and inside the buildings, or they might be fixed to the structures of buildings from the outside, e.g.:

- a tank inside a building, resting on the floor slab, on the ground slab or on the foundation (Fig. 6),

- a tank mounted to the structure of a building from the outside (Fig. 7).

Process and technical equipment mounted on special foundations, supporting structures, or to the structure of a building are not permanently affixed to land. For this reason, they may not be qualified as civil structures. 


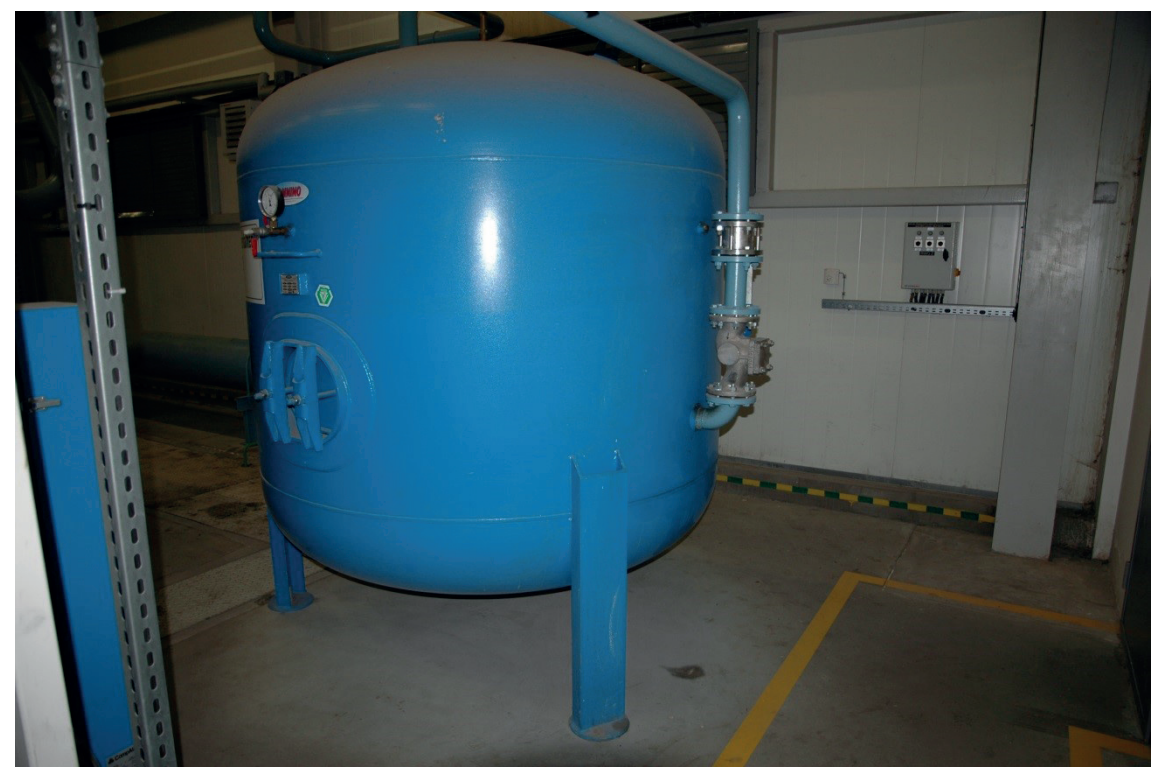

Fig. 6. Compressed air tank - elements of the process equipment resting on the floor in the process facility of the industrial plant

Source: [2]

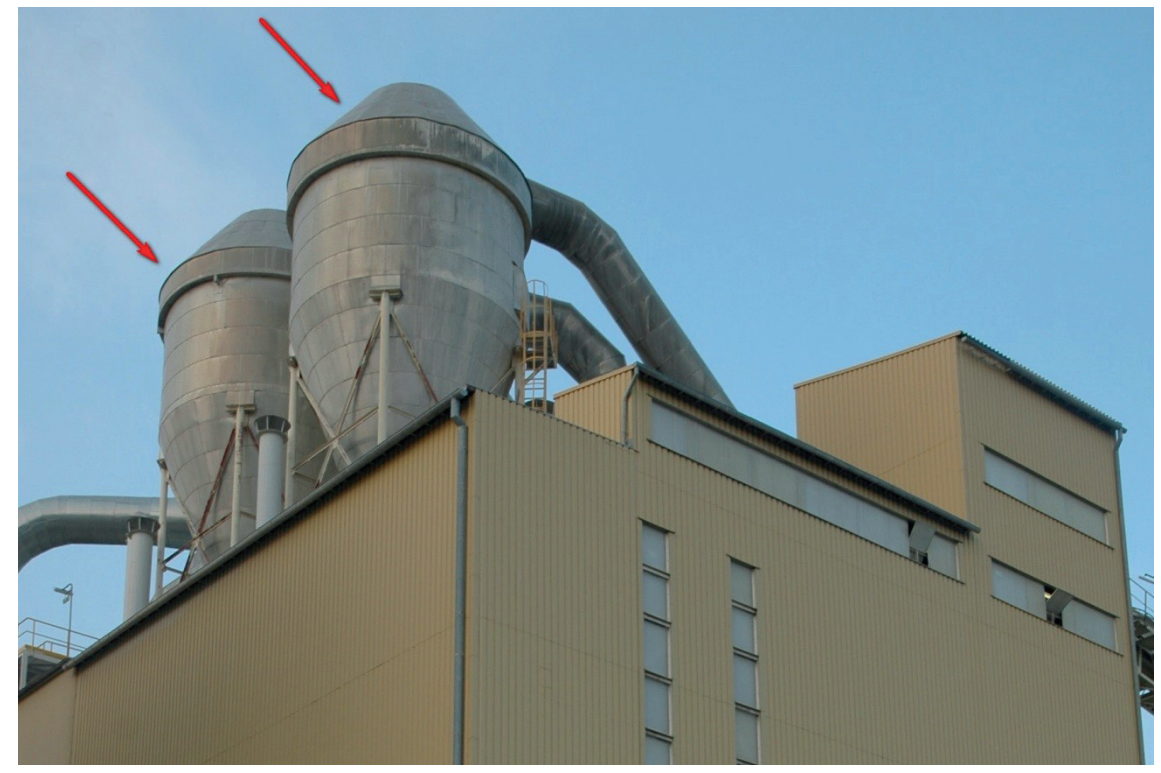

Fig. 7. Dedusting system tanks - elements of the process equipment based on the process facility at the industrial plant

Source: [2] 


\section{Foundations and Supporting Structures of Process Equipment or Technical Equipment}

In the case of foundations and supporting structures of process equipment or technical equipment, it should be assumed that they can be qualified as structures if they are separate objects that are permanently affixed to land. Foundations and supporting structures, together with installations and building's infrastructure, are structures, referred to in art. 3 of the Construction Law [5], provided that they constitute the technical and utility whole. In particular, the structures include e.g.:

- foundations, flyovers and engineering ducts with, e.g. pipelines, cable lines or devices that are part of the process line implemented in the plant; in this case, only constructions without equipment or devices are the structures (Figs 8, 9);

- foundations and supporting structures which operationally independent objects rest on; in this case, these constructions together with the objects resting on them, e.g. storage tanks, are the structures (Fig. 4);

- foundations or supporting structures located inside the building, which are civil structures separate from that building, and thus independent structures; such cases are very rare.

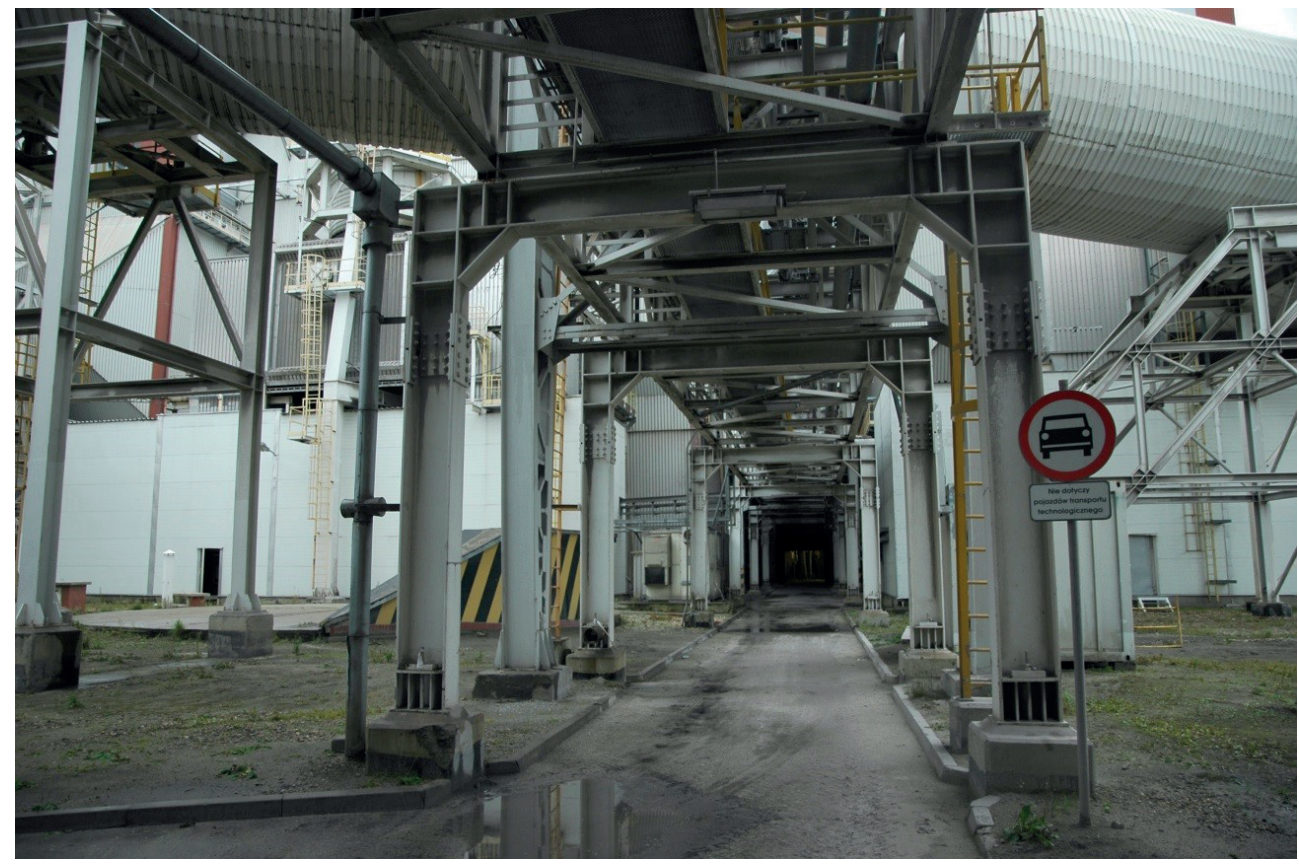

Fig. 8. Fragments of the engineering flyover with a steel frame structure. There are cables and pipelines on the flyover which are elements of the engineering process implemented in the plant - only the flyover is the structure

Source: [2] 


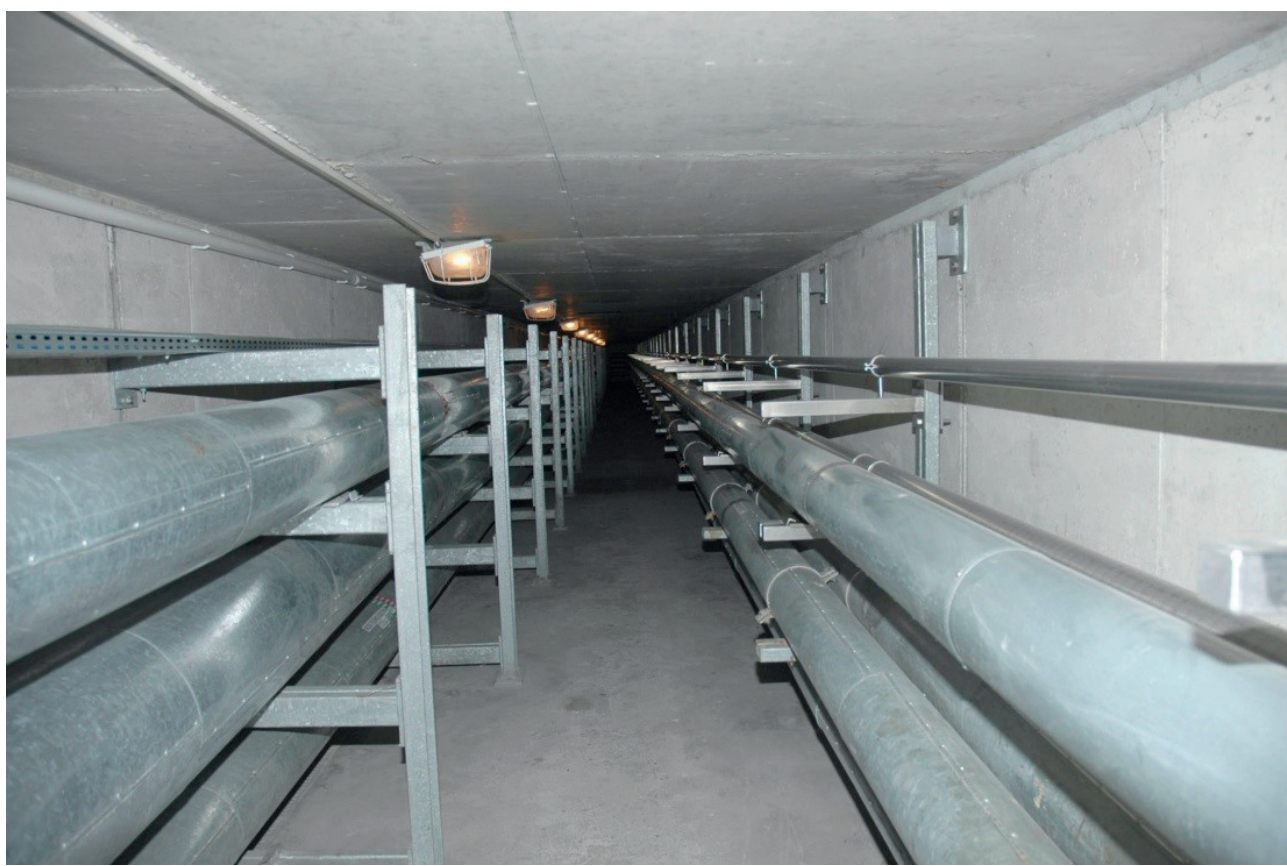

Fig. 9. Engineering duct between production buildings in the plant. The duct contains pipelines which are constituents of the engineering process implemented in the plant only engineering duct is the structure

Source: [2]

On the other hand, according to the criteria presented above, within the meaning of the Construction Law [5], the following objects are not structures:

- foundations and supporting structures of pipelines,

- cable lines,

- pumps,

- compressors,

- storage tanks,

which occur in the following forms:

- a supporting structure located inside the building and resting on its structural elements, such as foundation slab or floor slab (Fig. 10);

- floors inside a building, locally strengthened, for example by a plinth monolithically integrated thereto (Fig. 6);

- block (beam or frame) foundation, located inside the building, only separated from the building structure and the floor with a movement joint, but not being a civil structure, separate of the building (Figs 11, 12);

- a supporting structure located outside the building, mounted to the structure of the building or resting on its flat roof (Fig. 7). 


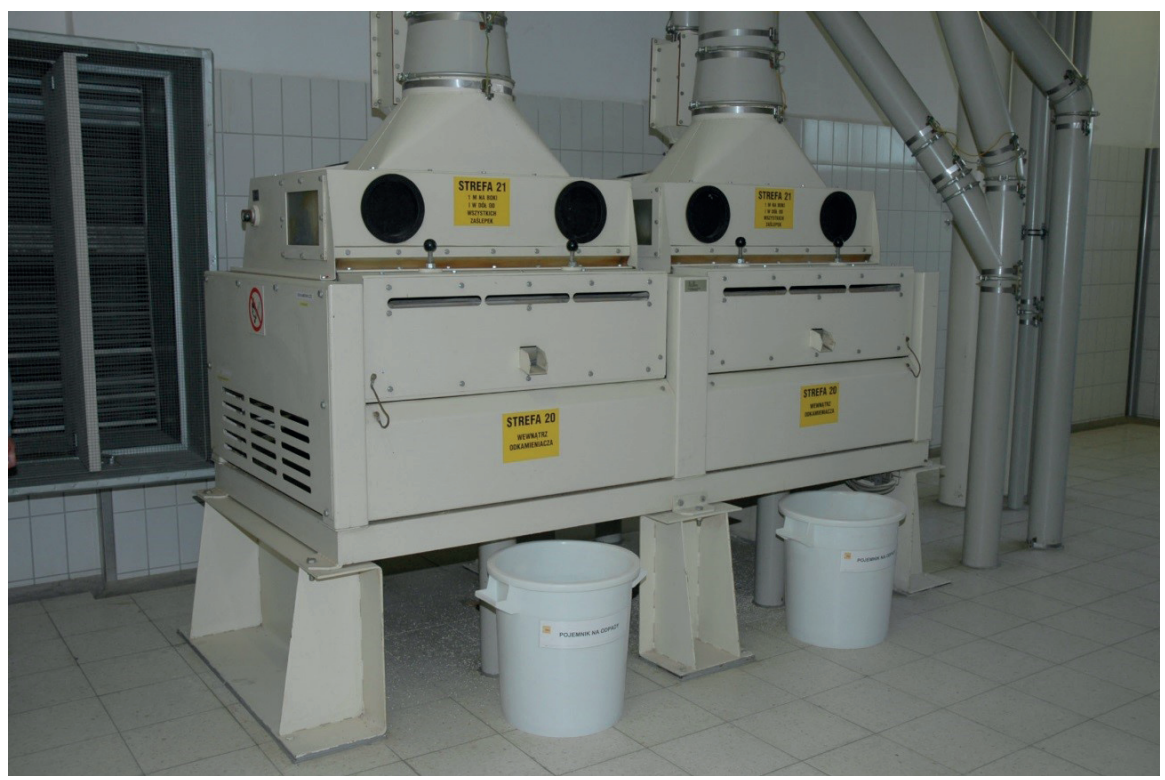

Fig. 10. A set of sieves resting on the floor slab in the production building of the industrial plant - the object is not the structure

\section{Source: [2]}

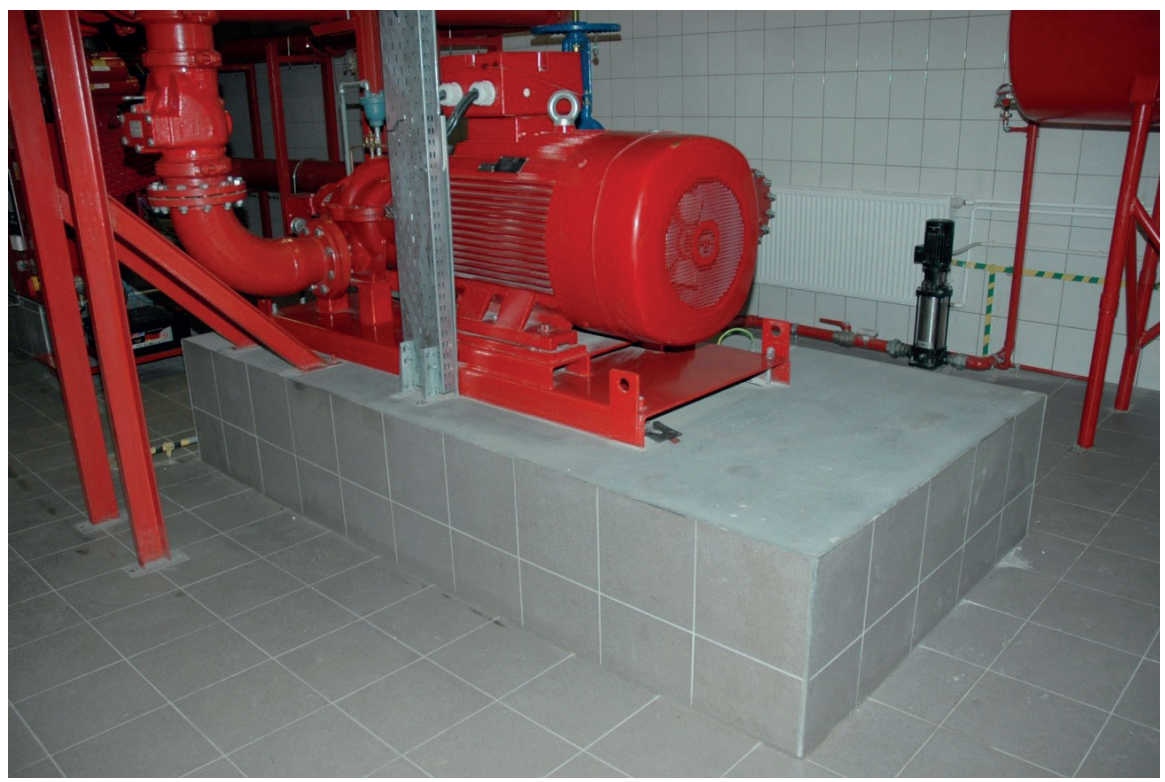

Fig. 11. Block foundation of the pump, located in the warehouse of the industrial plant the object is not the structure

$$
\text { Source: [2] }
$$




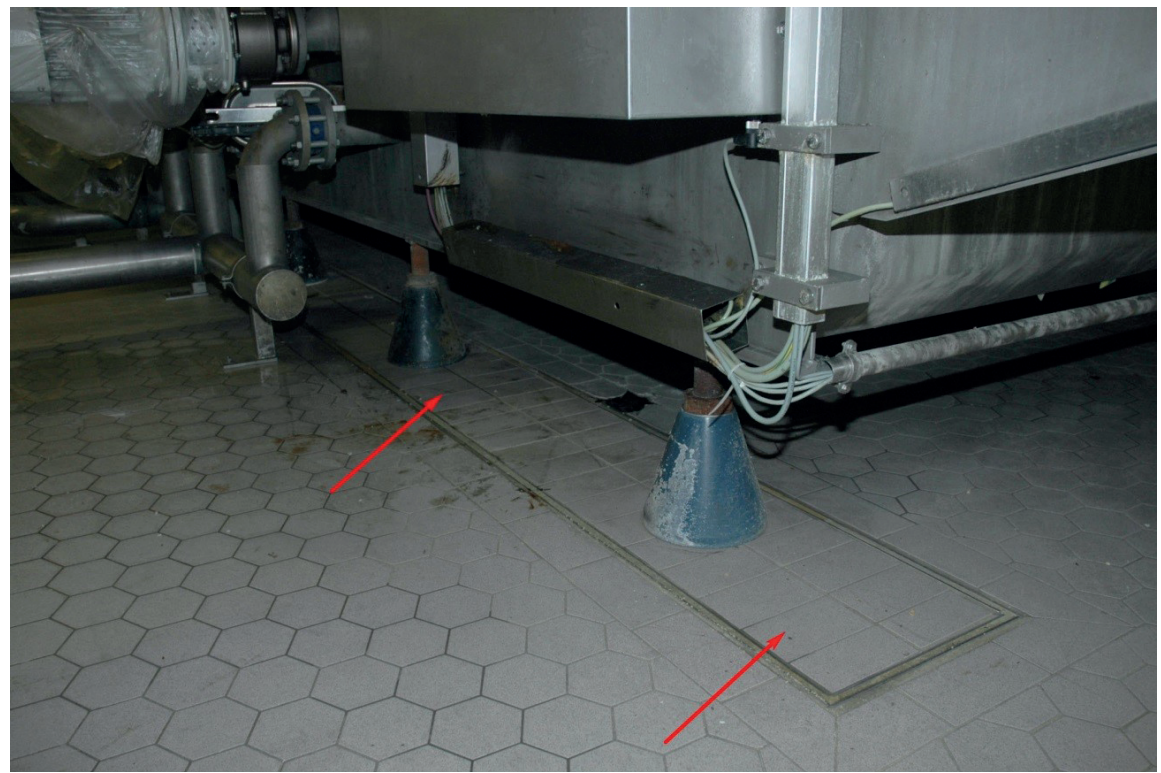

Fig. 12. Fragment of the beam foundation of the device located in the industrial plant production hall - the object is not the structure

Source: [2]

\section{Conclusions}

Industrial plants exhibit large diversity in fixed assets, both in terms of design solutions, as well as their functions in the engineering process. Imprecise naming of objects, which is inadequate to their function, is often encountered.

The paper presents criteria and examples of qualifying warehouses, storage tanks, reservoirs and foundations, supporting structures of technical equipment and process equipment associated with conducting business activity, in terms of charging property tax. Ambiguities contained in the legislation result in differences in interpretation as to the correct qualification of these objects in terms of the imposed tax, between representatives of industrial plants and administrative authorities. This often results in significant discrepancies in charging the tax due on fixed assets, and consequently, leads to lawsuits.

The above-mentioned factors prove that qualification of industrial assets, in terms of charging property tax, should be performed by construction specialists, who have the knowledge of engineering process implemented in the industrial plant, and of the construction law as well.

In accordance with the constitutional requirements, unclear tax regulations may not be interpreted to the detriment of taxpayers. 


\section{References}

[1] Firek K., Oruba R., Wodyński A.: Classification of building structures located in industrial plants with regard to calculating property tax. Geomatics and Environmental Engineering, vol. 8, no. 1, 2014, pp. 15-20.

[2] Opinie techniczne dotyczace kwalifikacji na gruncie ustawy Prawo budowlane wybranych składników majątku zakładów przemysłowych. Akademia Górniczo-Hutnicza im. Stanisława Staszica w Krakowie, Wydział Geodezji Górniczej i Inżynierii Środowiska, Katedra Geodezji Inżynieryjnej i Budownictwa, Kraków 2011-2014 [unpublished].

[3] Rozporzadzenie Ministra Infrastruktury z dnia 12 kwietnia 2002 r. w sprawie warunków technicznych, jakim powinny odpowiadać budynki i ich usytuowanie. Dz. U. 2002, nr 75, poz. 690 z późn. zm. [Journal of Laws 2002, no. 75, item 690 with amendments].

[4] Ustawa z dnia 12 stycznia 1991 r. o podatkach i opłatach lokalnych. Dz. U. 2002, nr 9, poz. 84 z późn. zm. [Journal of Laws 2002, no. 9, item 84 with amendments].

[5] Ustawa z dnia 7 lipca 1994 r. Prawo budowlane. Dz. U. 1994, nr 89, poz. 414 z późn. zm. Tekst jednolity: Dz. U. 2013, nr 142, poz. 1409 [Journal of Laws 1994, no. 89, item 414 with amendments, consolidated text: Journal of Laws 2013, no. 142, item 1409]. 